Zagadnienia Rodzajów Literackich, LX, z. 2

PL ISSN 0084-4446

DOI: $10.26485 / Z R L / 2017 / 60.2 / 2$

AnNa Zatora

Uniwersytet Łódzki*

\title{
Saga rodzinna - próba uporządkowania i konceptualizacji gatunku
}

Family Saga — an Attempt to Organize and Conceptualize the Genre

\begin{abstract}
This article presents a review of family sagas theory (family novels) as a genre. A family saga derives from Medieval Saga, but in contemporary meaning it is an extensive epic story about the history of the family. The purpose of the article is to organize earlier concepts and create a consistent model of a traditional family saga. It is also an introduction to the study of contemporary representations of this genre.
\end{abstract}


* Katedra Teorii Literatury, Instytut Kultury Współczesnej Wydział Filologiczny Uniwersytetu Łódzkiego

ul. Pomorska 171/173, 90-236 Łódź

e-mail: anna.zatora@gmail.com 


\section{Wprowadzenie}

We współczesnej genologii literackiej nadal można znaleźć obszary, które albo nie zostały jeszcze odkryte i dostatecznie zbadane, gdyż wiążą się z najnowszym, wciąż ewoluującym materiałem literackim, albo panuje w nich nieporzadek terminologiczny i konceptualny. W tak pojemnym gatunku epickim, jakim jest powieść, istnieje szczególnie dużo potencjalnych podgatunków czy odmian gatunkowych, mogących stanowić źródło inspiracji dla genologów. Zwłaszcza rozwijająca się i zyskująca powoli zainteresowanie badaczy literatura popularna zapewnia nowy materiał do analiz ${ }^{1}$. Jeśli sięgnąć jednak do odmian powieści bardziej zakorzenionych $\mathrm{w}$ tradycji genologicznej, można znaleźć przypadki tak skomplikowane, jak powieść rodzinna, która jest przedmiotem tej pracy.

Wydaje się, że problem z sagą rodzinna (powieścią rodzinna) ${ }^{2}$ dotyczy przede wszystkim nomenklatury - niekonsekwentnie stosowanej zarówno w dyskursie popularnym, publicystycznym, jak i przez samych badaczy. Mamy bowiem do czynienia z konwencjonalizowaniem się i przenoszeniem nazw genologicznych „dla oznaczenia innych przedmiotów genologicznych, takich nawet, które nie pozostają w genetycznym związk z tymi, z którymi dana nazwa była pierwotnie związana” (Skwarczyńska 1987: 98-99). Stefania Skwarczyńska sygnalizowała ten problem po raz pierwszy w 1966 roku na łamach „Zagadnień Rodzajów Literackich”, podkreślając konieczność konsekwencji i właściwego, nieprzypadkowego doboru terminów naukowych. To jednak tylko jedna strona zagadnienia. Druga, istotniejsza, wiąże się z samym przedmiotem badań i pytaniem, po pierwsze, o możliwość jego genologicznego uporządkowania oraz, po drugie — wyróżnienia w ogóle. Chaos terminologiczny i nachodzenie na siebie definicji co najmniej kilku znanych dziś odmian gatunkowych powieści powinny stanowić punkt wyjścia w rozważaniach nad sagą rodzinna.

We współczesnej genologii literackiej łatwo dostrzec dwa podstawowe bieguny: genologię tradycyjna, której przedstawiciele bronią raczej wyraźnych granic poszczególnych gatunków, oraz zwolenników opisu gatunku ujmowanego jako płynna, rozmyta kategoria

1 Warto wspomnieć choćby powieść graficzną czy powieść kryminalną, która z kolei rozgałęzia się, tworząc kolejne pododmiany gatunkowe.

2 Będę używała tych dwóch nazw naprzemiennie, optując jednak za terminem saga rodzimna na oznaczenie odmiany powieściowej, której charakterystykę opisuję. 
z trudnymi do wytyczenia granicami (Wojtak 2015: 18). Zdaniem Jerzego Bartmińskiego ci drudzy postrzegaja jako gatunki coś, co jest tylko wynikiem gier intertekstowych, różnego rodzaju przetwarzania, adaptacji i modyfikowania istniejących już pojęć (Bartmiński 2012: 16). Trudno odrzucić spostrzeżenie o istotności intertekstualnych czy innego rodzaju powiązań, choćby ewolucyjnych, lecz warto rozważyć ich wpływ na status genologiczny niektórych utworów literackich czy całych „ciagów gatunkowych”" Sposób definiowana gatunków literackich nasuwa inny podział, tzn. na model genologii strukturalistycznej i kognitywnej (Makuch 2015: 33) czy, jak nazywa to Bożena Witosz, model klasyczny i prototypowy (2005: 62-72). Pierwszy charakteryzuje gatunek, któremu wyznacza ostre granice: utwór jest lub nie jest powieścia/opowiadaniem/elegią musi mieć odpowiedni zestaw cech. Drugi model zaś opisuje prototyp, czyli wzorcowy przykład, wokół którego rozmieszcza inne utwory w odległości zależnej od natężenia podobieństwa; „utwór nie tyle przynależy do określonego gatunku, ile sytuuje się w polu jego wpływów" (Makuch 2015: 34). Coraz więcej badaczy odchodzi dziś od modelu strukturalistycznego, nie zawsze na rzecz genologii kognitywnej, ale zawsze dostrzegając niemożność wyznaczenia sztywnych granic gatunków literackich i to, że zmieniają się one w czasie. Już w 1979 roku Tzvetan Todorov pisał o spójności konwencjonalnej, stwierdzając, że gatunki to nie prosta reprodukcja aktów mowy, lecz seria ich przekształceń i amplifikacji (Todorov 1979). Zwrot kulturowy w badaniach literackich sprawil, że autorytarny dyskurs klasycznej genologii otworzył się na inne koncepcje, m.in. te koncentrujące się na marginalnych czy tłumionych aspektach badań nad gatunkami. Kulturowa teoria gatunku stała się pewnego rodzaju alternatywą, unikającą historyczności, wartościowania i konstruktywizmu (Makuch 2015: 36; Sendyka 2006), sięgającą natomiast m.in. do antropologii, a więc interdyscyplinarna. Obranie takiej drogi wydaje się słuszne zwłaszcza w przypadku gatunku ${ }^{4}$ tak silnie związanego z rzeczywistościa pozaliteracka, jak właśnie saga rodzinna.

Trudno określić czas powstania pierwszej powieści rodzinnej. Danuta Szymonik, badaczka zajmująca się rosyjską powieścią rodzinną przełomu XIX i XX wieku (,wiek srebrny”, ros. Серебряный век, w kulturze rosyjskiej), słusznie wskazuje na Biblię jako źródło opowieści rodowych, ale za pierwszy utwór skonstruowany wokół relacji rodzinnych uważa Gargantue i Pantagruela François Rabelais'go, a więc tekst renesansowy (Szymonik 2003: 58). Oczywiste jest, że konflikty rodzinne i tematykę rodzinną w ogóle można znaleźć we wszystkich okresach literackich. W niektórych, jak choćby w tragedii greckiej, zaznaczaja się silniej, w innych słabiej lub są odpowiednio ideologizowane, na przykład w socrealizmie. Nie podlega jednak watpliwości, że rodowód to jeden z najważniejszych sposobów wyrażania tożsamości przez człowieka.

Badacze przekazów dotyczących rodziny w folklorystyce, etnologii i antropologii sięgają nie tylko do tradycji pisanej, ale i do ustnej. Folklorystyczno-antropologiczne family history sa pokrewne badawczo z oral history - to historie rodzin zapisywane na postawie ustnych opowieści (Złatanowa 1993: 49-50). Tego rodzaju przekazami zajmowano się szczególnie intensywnie, gdy rozkwitał etiologizm, jedna z faz folkloru amerykańskiego. Wówczas powstał także termin saga rodowa (ang. family saga) na określenie przekazu, który „obrasta

3 Termin autorstwa Stefana Sawickiego, oznaczający zbiór utworów literackich sąsiadujących ze sobą czasie i współtworzących konkretny gatunek (zob. Sawicki 1976: 209, cyt. za: Wojtak 2015).

4 Mowa oczywiście o odmianie gatunkowej, jednak ze względu na stylistyczne aspekty tekstu niekiedy stosuję to uproszczenie. 
wokół rodziny lub rodzinnych patriarchów względnie »matriarchów«, a który przechowywany jest oraz modyfikowany poprzez ustny przekaz, wreszcie uważany jest za szczerą prawdę" (Boatright 1973: 124, cyt. za Złatanowa 1993: 53). W zbiorach folklorystycznych zwykle brak jednak podań rodowych. Zdaniem Nadii Złatanowej „nosiciele folkloru” wstydzą się prywatnych historii, nie chcą zdradzać rodzinnych tajemnic, co jest oczywistą strata poznawcza. Badaczka pisze: „W moim przekonaniu właśnie rozważania nad poetyką przekazów rodowodowych mogą dać jeden z najważniejszych kluczy do odnalezienia zawartych w nich idei wspólnoty" (1993: 51). Pisane przekazy o rodzinie można znaleźć natomiast w tzw. pisarstwie ludowym (pisarstwie chłopskim). Zarówno świadectwa ustne, jak i spisane historie rodzinne, które zajmują folklorystów, są jednak traktowane z pobłażaniem przez heraldyków i historyków badających historię rodziny i ignorowane jako nieprofesjonalne i nieudokumentowane (Złatanowa 1993: 48).

O tym, jak ważne są źródła o tematyce rodzinnej, nie trzeba przekonywać zatem antropologów i etnologów ani innych badaczy kultury. Również literaturoznawcy poświęcili tym zagadnieniom wiele prac, a ich autorami są m.in.: Małgorzata Medecka (apokryf rodzinny; 2007), Danuta Szymonik (rosyjska powieść rodzinna; 1987, 1994, 1997, 1999 , 2003), Anna Frydrychs (rozprawa doktorska poświęcona powieści-rzece; 1965), Małgorzata Czermińska (tematyka domu i dzieciństwa w autobiografii; 2000, 2009), Monika Brzóstowicz (wizerunek rodziny w polskiej prozie współczesnej; 1998), Krystyna Jakowska (cykl w literaturze; 2001, 2005, 2011). Wśród prac genologicznych warto wymienić też takie teksty, jak artykuły-hasła słownikowe publikowane na łamach czasopisma „Zagadnienia Rodzajów Literackich”, które potem ukazały się w słowniku genologicznym pod redakcją Grzegorza Gazdy i Słowinii Tyneckiej-Makowskiej — nie dotyczą one co prawda stricte tematu rodziny jako wyznacznika gatunkowego, ale charakteryzuja gatunki i odmiany gatunkowe będące ważnym kontekstem dla moich rozważań (hasła: powieść, powieść-rzeka, powieść-kronika, powieść historyczna, powieść psychologiczna, powieść realistyczna, saga). Pomijam tu prace na temat sagi jako gatunku historycznego i wiele istotnych tekstów genologicznych dotyczących w różnym stopniu interesującego mnie problemu, które czytelnik znajdzie w bibliografii. Choć literatura przedmiotowa jest obszerna, wspomniane już nieuporządkowanie terminologiczne skłania do rekonesansu i ponownego przyjrzenia się problematyce powieści rodzinnej.

\section{Problemy z nomenklaturą}

Badania nad sagą rodzinną należałoby zacząć od przyjrzenia się terminowi saga i gatunkowi, który znany jest pod tą nazwą. Diachroniczne podejście do przedmiotu analiz wydaje się naturalne i typowe - zwykle tak postępuje się, rozpoczynając pracę nad gatunkiem literackim. W przypadku powieści rodzinnej warto jednak równolegle przeprowadzić przegląd określeń i terminów stosowanych do opisu niekiedy tożsamych zjawisk literackich, a na pewno zjawisk ściśle związanych z utworami mieszczącymi się w obrębie moich zainteresowań badawczych. Można zauważyć, że na przestrzeni kilkudziesięciu lat pojawiło się wiele mocniej lub słabiej scharakteryzowanych odmian gatunkowych powieści, które podejmuja temat rodziny. Niekiedy staje się on dominantą nie tylko semantyczna, ale i kompozycyjna. W słownikach terminów i gatunków literackich funkcjonuje tylko część z nazw określających tego typu utwory, są to przede wszystkim powieść-rz̨eka i powieść kronika lub kronika rodżinna, natomiast sage — jako gatunek historyczny — można dołączyć do nich, 
opierając się na haśle autorstwa Natalii Lemann zakończonym słowami: „Współcześnie mianem sagi określa się obszerne utwory epickie osnute wokół dziejów wielopokoleniowej rodziny” (2012: 978), a także na popularnej definicji Stanisława Sierotwińskiego: „W czasach nowszych określenie to nadaje się utworom epickim z przeszłości, osnutym na dziejach bohatera lub rodziny" (1966: 242).

W rozprawie doktorskiej na temat odmiany gatunkowej roman-flewve (powieśsi-ržeki) Anna Frydrychs stwierdza, że nie jest to termin naukowy, gdyż brakuje zgodnej definicji pojęcia (1965: 3). Już wówczas, w latach 60. XX wieku, zauważano brak uporządkowania terminologicznego w zakresie odmian (odmiany?) powieści rodzinnej. Badania przeprowadzone w oparciu o literaturę polsko-, niemiecko-, francusko- i anglojęzyczną przynoszą następujące nazwy stosowane do opisywania tych samych lub pokrewnych utworów literackich: roman-cycle, roman-epopeja, kronika rodzinna, saga-novel, saga, cyclic novel, roman-somme (Frydrychs 1965: 51-60). Są to tylko synonimy dla powieści-rzeki ${ }^{5}$. W dalszej części niniejszego tekstu skonfrontuję ze sobą nie tylko terminy, ale i ich desygnaty, tzn. charakterystykę roman-fleuve $\mathrm{i}$ innych, pokrewnych odmian powieści.

Podobną niekonsekwencję nomenklaturową można znaleźć w tekstach Danuty Szymonik. Oprócz tytułowej powieści rodżinnej w pracach badaczki pojawiają się: kronika rodżinna (1994: 101; 1999: 138), powieść rodowa (1997), saga, zapisana w cudzysłowie (2003: 174), a raz bez cudzysłowu (1987), i „typ tzw. sagi rodzinnej” (1994: 96), ponadto nietożsama z powieścią rodzinną kronika (2003: 110). Warto podkreślić, że autorka Rosyjskiej powieść rodzinnej Srebrnego Wieku używa terminów saga i saga rodzinna przede wszystkim w odniesieniu do utworów z zachodnioeuropejskiego kręgu kulturowego, m.in. Buddenbrooków Thomasa Manna czy Sagi rodu Forsythów Johna Galsworthy'ego, zaś kronika rodzinna i powieść rodżinna oznaczają analizowane przez nią utwory rosyjskie i pokrewne kulturowo, w tym polskie.

Termin czy raczej określenie powieść rodżinna pada również w pracy Jana Wierzbickiego o Miroslavie Krlezie (Wierzbicki 1975: 227), poza tym wykorzystywane jest raczej jako synonim dla innych nazw niż jako pojęcie o konkretnym ładunku znaczeniowym. Ivo Pospíšil, piszacc o powieśsi kronice, stosuje termin powieść pokoleniowa (2012: 791). Z kolei Monika Brzóstowicz wymienia gatunki „przedstawiające losy ludzkie w porządku genologicznym": idyllę rodzinną, baśń, sagę, kronikę rodzinną, powieść-rzekę, powieść mitu rodzinnego, traktując je odrębnie. Pisząc o sadze i pokrewnych jej powieści-rzece i kronice rodzinnej, badaczka wyraźnie wyodrębnia co najmniej trzy różne odmiany gatunkowe (1998: 151). Saga rodżinna pojawia się zaś w jej pracy na określenie Wariacji poczłtowych Kazimierza Brandysa (1998: 164).

Sagę spośród gatunków „rodzinnych” wyróżnia także Małgorzata Medecka, traktując ją jako kontekst rozważań nad Apokryfem rodzinnym Hanny Malewskiej (Medecka 2007: 12). Nie precyzuje jednak, dlaczego używa tego właśnie terminu. Sam przedmiot badań, utwór Malewskiej z 1965 roku, służy za prototyp gatunkowy: od jego tytułu badaczka ukuła nazwę gatunku apokryf rodzinny, traktując apokryficzność ${ }^{6}$ jako metaforę (Medecka 2007: 9). Do apokryfów rodzinnych zalicza wybrane utwory Teodora Parnickiego, Kazimierza Brandysa, Andrzeja Kuśniewicza, Tadeusza Konwickiego i Stefana Chwina. W odniesieniu

5 Warto dodać, że niedoskonały, ale najpopularniejszy internetowy tłumacz, Google Translate, tłumaczy francuskie „roman-fleuve” jako „saga”.

6 Najpełniejszą definicję apokryfu literackiego można znaleźć w artykule-haśle autorstwa Danuty Szajnert (2014) oraz w innych tekstach badaczki, m.in. w artykule Mutacje apokeryfu (Szajnert 2000). 
do tych tekstów pada także określenie „beletryzowane kroniki” (Medecka 2007: 61). Sama Hanna Malewska o Apokryfie rodzinnym mówi jako o: dziejach rodzinnych, kronice, historii rodzinnej, eseju rodzinno-socjologicznym (Brzóstowicz 1998: 184).

Zamykając to krótkie zestawienie terminologiczne, warto przywołać raz jeszcze definicję współczesnej sagi autorstwa Lemann („obszerny utwór epicki osnuty wokół dziejów wielopokoleniowej rodziny") oraz definicję powieści-rzeki autorstwa Stanisława Sierotwińskiego: ,wielotomowy cykl powieści przedstawiających dzieje rodziny przez kilka pokoleń” (1966: 203). Wynika z tego, że saga rodzinna byłaby obszernym utworem, natomiast powieść-rzekę odróżniałaby od niej jedynie cykliczność czy wielotomowość, co jest łatwym do podważenia twierdzeniem, czego dokonała już Anna Frydrychs, definiując roman-fleuve.

Oprócz różnych nazw na określenie pokrewnych, a nierzadko tych samych utworów literackich warto zauważyć, iż w centrum zainteresowania badaczy znajdują się i powtarzają niektóre tytuły będące egzemplifikacjami często kilku różnych — z założenia odmian powieściowych. Przede wszystkim, na gruncie polskim, sa to Noce $i$ dnie Marii Dąbrowskiej. Powieść jest charakteryzowana jako: saga współczesna, powieść rodzinna, powieść realistyczna, powieść-rzeka, powieść psychologiczna (psychologiczno-obyczajowa). Nieco mniej odmian reprezentuje Nad Niemnem Elizy Orzeszkowej, bo tylko: powieść realistyczną, powieść-rzekę i powieść rodzinną. Najczęściej pojawiającym się przykładem, zarówno sagi współczesnej, jak i powieści-rzeki, powieści pokoleniowej i kroniki rodzinnej, sa Buddenbrookowie Thomasa Manna. Jako sagi i jako powieści-rzeki rozpatrywane są również: Saga rodu Forsythe'ów Johna Galsworthy'ego, Kronika rodu Pasquier Georgesa Duhamela, Rodzina Whiteoaków Mazo de la Roche. Z kolei Cichy Don Michaiła Szołochowa to: powieść realistyczna, powieść-rzeka i powieść historyczna. Cechy powieści historycznej ma powieść Joanny Olczak-Ronikier $W$ ogrodžie pamiecci, którą opisuje się jako sagę. Badacze wymieniają jeszcze Sage o Ludziach Lodu Margit Sandemo czy Krystyne, córke Lavransa Sigrid Undset.

Te najczęściej pojawiające się reprezentacje literackie o niejasnej kwalifikacji gatunkowej, mające zarazem wspólne cechy, pozwalają stwierdzić, że istnieje potrzeba uporządkowania terminologicznego w zakresie badań nad powieścią rodzinną. Kolejnym aspektem jest stosowanie terminu saga w dyskursie popularnonaukowym i publicystycznym, niekiedy też naukowym, w sposób swobodny na opisanie różnych zjawisk literackich i okołoliterackich, nie zawsze nawet pozostających ze sobą w związku. Mamy zatem sagę rozumianą historycznie, o czym w dalszej części tekstu, sagę jako serię powieściowa, najczęściej skupioną wokół jednego bohatera (saga o Wiedźminie Andrzeja Sapkowskiego czy saga o Harrym Potterze J. K. Rowling) oraz sagi jako wszelkie fikcjonalne i niefikcjonalne opowieści o rodzinie, w tym: beletrystykę, kroniki, wspomnienia, biografie („saga” pojawia się często wprost w tytułach utworów, np. Pendereccy. Saga rodzinna). Warto rozważyć, czy wszystkie te zakresy znaczeniowe maja wspólny mianownik i czy możliwe jest opisanie wszystkich lub przynajmniej większości wymienianych tekstów literackich za pomoca jednej, nadrzędnej odmiany gatunkowej.

\section{Ujęcie diachroniczne i pokrewne odmiany gatunkowe}

Ujęcie diachroniczne w badaniach nad sagą rodzinną odsyła do genezy samej nazwy i do pierwotnego gatunku historycznego, czyli staroskandynawskiej sagi (1. mn. sögur, od staronordyjskiego czasownika segja 'mówić, opowiadać', sagða 'powiedziałem/powiedziałam'). 
„Pierwotnie zatem słowo to oznaczało mniej więcej tyle, co »opowiedziane« czy »zrelacjonowane «, dodatkowo akcentując ustny charakter przekazu najstarszych dzieł literatury islandzkiej" (Morawiec, Neubauer 2015: 8). Jako gatunek historyczny saga została dobrze scharakteryzowana — prócz najnowszej pracy na temat sag islandzkich pod redakcja Jakuba Morawca i Łukasza Neubauera (2015) w języku polskim ukazało się kilka ważnych publikacji, m.in. Sagi islandqkie opracowane przez Artura Górskiego (1960) czy przekłady tekstów Margaret Schlauch (1976). W tym pierwotnym rozumieniu saga to termin na oznaczenie staroskandynawskich, przede wszystkim islandzkich, średniowiecznych dzieł prozy narracyjnej spisanych w XIII-XIV wieku. Przyjął się podział sag na trzy kategorie: sagi królewskie — opisujące dzieje królów, najczęściej norweskich (panujących od IX do XIII wieku); s a gi le ge nda r ne - opisujące wydarzenia sprzed kolonizacji Islandii, zawierające elementy fantastyczne; s a gi rodowe - dotyczące wydarzeń mających miejsce na Islandii w latach 870-1030 i opisujące dzieje poszczególnych rodów (Lemann 2012: 975). Te ostatnie najbardziej mogą kojarzyć się ze współczesnymi sagami rodzinnymi ze względu na wątek przewodni, jakim są losy rodu. Ważnym aspektem jest pierwotna oralność sag islandzkich. Różnie ocenia się ich wiarygodność historyczną sagi legendarne i rodowe sa najmniej mocno osadzone w historii, jednak zawierają wiele potwierdzonych informacji, choćby dane dotyczące sukcesji. Można by mówić za Nadia Złatanową o prawdzie synkretycznej: połączeniu prawdy historycznej i prawdy artystycznej (1993: 51). W kulturze europejskiej sagi pojawiły się w XIX wieku (tłumaczenia Williama Morrisa na języka angielski) i uderzały wówczas obiektywizmem narracji przypominającym europejski realizm czy naturalizm (Lemann 2012: 978).

W niemal wszystkich słownikach gatunków i terminów literackich pojawia się dopisek o współczesnym rozumieniu terminu saga, na które zwracałam już uwagę. Warto jednak zaznaczyć, że w ujęciu historycznym termin saga współczesna również funkcjonuje i oznacza podgatunek sagi, niemający jednak nic wspólnego z powieściami rodzinnymi. Sagi współczesne — w odróżnieniu od sag jako takich — sygnalizują, że dotyczą wydarzeń współczesnych ich autorowi (Skrzypek 2015: 100-101). Ten podgatunek sagi byłyby więc przeciwieństwem sag rodowych, których akcja osadzona była w odległej przeszłości. Dlatego też określenie saga wspólçesna nie powinno być stosowane do opisywania kontynuacji gatunku historycznego w postaci współczesnych utworów narracyjnych o rodzinie.

Słowniki definiują sagę jako gatunek średniowieczny, wskazując na dzisiejsze pojmowanie tego terminu. Sierotwiński tak kończy hasło saga: „W czasach nowszych określenie to nadaje się utworom epickim z przeszłości, osnutym na dziejach bohatera lub rodziny" (1966: 242). W ujęciu Lemann nie pojawia się już „bohater” ani „przeszłość”, badaczka koncentruje się na „rodzinie” i podaje przykłady: „Współcześnie mianem sagi określa się obszerne utwory epickie osnute wokół dziejów wielopokoleniowej rodziny (np. John Galsworthy Saga rodu Forsythe'ow, Tomasz Mann Buddenbrookowie, Margit Sandemo Saga o ludziach lodu, Sigrid Undset Krystyna córka Lawransa, Joanna Olczak-Ronikier W ogrodzie pamięci)" (2012: 978). Podobne cechy kontynuacjom sag przypisują inne, także popularne słowniki gatunków i terminów literackich (Bernacki, Pawlus 2002: 204; Stownik terminów literackich 2008: 495). Nieco inaczej charakteryzują współczesne użycie terminu redaktorzy tomu poświęconego sagom islandzkim — zwracają oni uwagę na wejście sagi do słownika codziennego, gdzie oznacza ona „obszerne, nieraz wielowątkowe narracje współczesne” 
(Morawiec, Neubauer 2015: 8). Zatem tym, co powtarza się we wszystkich definicjach, jest epickość (także narracyjność) i obszerność. W większości ujęć ponadto powraca tematyka rodzinna.

Podobnie rzecz wygląda w opracowaniach zagranicznych. Słowniki definiują sagę jako „a long story composed in medieval times in Norway or Iceland” (Collins Cobuild English Dictionary 1995: 1468), "a medieval Icelandic or Norse prose narrative of the achievements and events of a person or a family" (The RandomHouse Collage Dictionary 1984: 1161), Cambridge Advanced Dictionary, nowszy słownik, podaje także drugie znaczenie słowa: „series of related usually negative events” (Cambridge Advanced Dictionary 2013: 1358). Jako niewłaściwe użycie terminu pojawia się definicja: "a story, popularly believed to be matter of fact, which has been development by gradual accretions in the course of ages, and has been handed down by oral tradition" (The Oxford English Dictionary 1991: 364). W niemieckich słownikach zwraca się uwage na etymologię, która podobnie jak w językach staroskandynawskich wiąże „sagę” z mówieniem, opowiadaniem, a ponadto wskazuje się na folklorystyczne korzenie gatunku (Duden Deutsches Universalworterbuch 2015: 1495).

Anna Frydrychs, pisząc o powieści-rzece, zauważa pewne związki pomiędzy przedmiotem swoich badań a średniowieczną sagą rodową, wskazując na analizy Artura Górskiego (1965: 241). Badacz wymienia bowiem cechy charakterystyczne dla sag islandzkich z okresu 872-1030: „Głód rzeczywistości, skłon do spraw rodzinnych, badawcze ujęcie charakteru jako źródła ludzkich poczynań, tudzież hierarchia wartości skierowana ku humanitaryzmowi” (1960: 281). Są one na tyle uniwersalne, że mogą wskazywać na związek zarówno z roman-fleuve, jak i innymi, pokrewnymi odmianami powieści, o których pisałam w poprzedniej części tekstu. Biorąc pod uwagę te cechy, a zatem: realistyczność, skupienie się na tematyce rodzinnej, elementy psychologiczne i określony system wartości, a ponadto pierwotną oralność typową też dla folklorystycznych przekazów o rodzinie (gawędziarstwo), można nazwać powieść rodżinna (sage rodzinna) pewnego rodzaju kontynuacja gatunku historycznego.

W oparciu o prace dotyczące pokrewnych odmian gatunkowych można wysnuć pewne wnioski na temat współcześnie funkcjonującego rozumienia sagi rodzinnej czy też powieści rodzinnej. Konieczne jest wychwycenie cech przypisywanych utworom zaliczanym do tychże zbliżonych odmian powieści, takich jak apokryf rodzinny czy powieść-rzeka, by wydobyć ewentualne różnice pomiędzy nimi a przedmiotem moich rozważań.

Małgorzata Medecka tak definiuje apokryf rodzinny, wyodrębnioną i nazwaną przez siebie odmianę powieści historycznej:

Swoistość apokryfu rodzinnego określa tematyka dotycząca minionych zdarzeń — są to dzieje rodziny w różnym stopniu schematyczne i fragmentaryczne — prócz tego postawa autobiograficzna i autotematyzm wyrażone explicite jak też implikowane przez powieściowe struktury. Moment historyczny uzupełniany bywa w tych tekstach elementami współczesnymi, autobiograficznymi, co także pojmować można jako implicytny komentarz do zagadnień związanych z narracją o przeszłości. (Medecka 2007: 8)

Do najważniejszych cech opisywanej odmiany gatunkowej należą ponadto: sygnatura biograficzna, na ogół z narracją personalna, nawiązanie do staropolskiego herbarza, sygnalizowanie niekompetencji faktograficznej twórcy (Medecka 2007: 63). Powstałe na gruncie 
pamięci luki autor apokryfu wypełnia fragmentami fikcji. Stopień ich zgodności z faktami i historią bywa bardzo zróżnicowany i nie jest najistotniejszy. W tych „beletryzowanych kronikach", jak pisze Medecka, genealogia jest bowiem tworzona, a nie odtwarzana (2007: 61).

Powieść rodzinna jest przez badaczkę traktowana jako literacki pierwowzór apokryfów rodzinnych. Zarówno jeden, jak i drugi gatunek konstruuje genealogię i „odtwarza pewne procesy, usiłuje przeniknąć «mroki przeszłości»” (Medecka 2007: 64). Naturalne wydaje się, że musi dokonywać przy tym selekcji, a tym samym posługiwać się fragmentarycznościa — w przypadku apokryfu rodzinnego wybiórczość dotyczy faktów, a w przypadku sagi, posługującej się fikcją w o wiele większym stopniu, nie jest to sprecyzowane. Medecka podkreśla, że apokryf od sagi odróżnia wrażenie autentyczności: w toku opowiadania łączy się tu pakt autobiograficzny, referencjalny i powieściowy (2007: 64). Owo połączenie powieści i faktografii, fikcji z autentycznościa, sprawia, że apokryf rodzinny uznawany jest za specyficzną odmianę powieści historycznej. W sagach z kolei, jak twierdzi badaczka, ród jest w całości konstruowany, a więc narrator ma dystans i wykazuje się niezmienną postawą wobec świata przedstawionego. Apokryf, będący rekonstrukcją, sprawia, że stosunek narratora ulega zmianie, dystans zostaje zmniejszony (Medecka 2007: 86). Niewątpliwie takie rozgraniczenie możliwe jest tylko wtedy, gdy sagę rodzinną utożsamimy z kilkoma reprezentującymi ją w słownikach przykładami, przy czym najczęściej kojarzy się ona z Buddenbrookami Thomasa Manna, w przypadku których mimo wszystko obiektywna postawa narratora nie jest tak oczywista. Co ciekawe, Danuta Szymonik także zwraca uwagę na obiektywizm narracji sag zachodnioeuropejskich, który odróżniałby je od południowosłowiańskich czy szerzej — wschodnioeuropejskich (2003: 180).

Drugim gatunkiem, który pojawia się w zestawieniu z sagą rodzinną, jest kronika czy powieść kronika. Kryterium wyodrębnienia stanowiłaby w tym przypadku tematyka: „W odróżnieniu jednak od kroniki, w której daje się zauważyć brak wyraźnie zaznaczonego ośrodka organizującego kompozycję, powieść rodzinna osnuta jest wokół dziejów rodziny" (Szymonik 2003: 110). Wyznacznik semantyczny gatunku literackiego nie byłby niczym nowym w tradycji genologicznej — już w 1954 roku Skwarczyńska pisała o „linii myślowej całości” jako wyróżniku gatunku (1954: 458-459).

Temat byłby z kolei tym, co łączy sagę rodzinną z powieścią-rzeka zdefiniowaną przez Frydrychs. Badaczka przypisała analizowanym przez siebie utworom określony zestaw cech (1965: 223):

a. czas jako zasadniczy element struktury utworu,

b. czas fabuły obejmujący co najmniej dziesięć lat,

c. dążenie do wiernego odtworzenia rzeczywistości pozaliterackiej,

d. wysoka ranga codzienności,

e. wnikliwa analiza postaci,

f. epicka rozlewność narracji.

Jako teksty literackie spełniające powyższe kryteria wskazuje m.in.: Noce $i$ dnie Dąbrowskiej, Kronike rodu Pasquier Duhamela, Sage rodu Forsythe'ów Galsworthy'ego, Rodzine Whiteoaków de la Roche i Buddenbrooków Manna. 
Tak scharakteryzowana powieść-rzeka wykazuje duże podobieństwo ze współcześnie rozumianą sagą rodzinną czy też powieścią rodzinną w ujęciu Danuty Szymonik. Jeżeli by oprzeć się tylko na tych wymienionych wyżej cechach i dodać aspekt tematyki rodzinnej, można by uznać je za gatunki tożsame. Jaki obraz powieści rodzinnej wyłania się z analiz powieści rosyjskich i zestawienia ich z zachodnioeuropejskimi sagami rodzinnymi?

Punktem wyjścia ponownie należy uczynić tematykę. Jak zauważa Szymonik: „Twórców polskiej i rosyjskiej kroniki rodzinnej fascynuje przede wszystkim sama egzystencja ludzka, sprzężona z rytmem biologii, czasu i historii” (1994: 101). Tak można by najogólniej opisać istotne zależności pomiędzy poszczególnymi postaciami, których relacje opieraja się na następowaniu po sobie kolejnych pokoleń (dialog i konflikt), a światem zewnętrznym, zwłaszcza Historia. Przeobrażenia społeczno-kulturowe stanowią tło dla losów postaci — najczęściej jednego rodu przedstawionego na przestrzeni co najmniej kilkunastu, a czasem kilkudziesięciu lat. Opisywane rody należą przeważnie do środowiska burżuazyjno-kupieckiego oraz warstwy ziemiańsko-szlacheckiej, które to stany ukazane sa w czasie, gdy powoli odchodzą z areny historycznej (Szymonik 2003: 174-175). Kryterium semantyczne staje się dominantą konstrukcyjną utworu:

Do najważniejszych cech gatunkowych powieści rodzinnej należy prezentacja egzystencji kosmosu rodowego. Jego obraz jest kreowany za pośrednictwem działań postaci, ich myśli, wypowiedzi, fabuły oraz motywów, toposów i chronotopu. Wymienione elementy współtworzą całość artystyczną omawianej odmiany gatunkowej. (Szymonik 2003: 57)

Jako ważne komponenty strukturalne Szymonik wymienia także: „mitologem” gniazda rodzinnego, wielopokoleniowość, konflikt ojców i dzieci; ponadto refleksję natury psychologicznej, stany chorobowe i patologiczne (2003: 129). Fabuła tworzy się w oparciu o struktury postaci. W analizowanych przez badaczkę powieściach kompetencje narratora sa mocno ograniczone, co powoduje, że bohater i narrator „oddalają się od siebie”. Neutralna narracja odautorska, obiektywizm oraz relacje czasowoprzestrzenne odpowiadające rzeczywistym stanowią nawiązanie do XIX-wiecznych norm pisarskich. Zgodność czasu zdarzeń z czasem faktycznym jest niekiedy tak dokładna, np. u Manna czy Galsworthy'ego, że przywodzi na myśl średniowieczne kroniki genealogiczno-rodowe (Szymonik 2003: 170-172). Szymonik zauważa, że mimo podobnej tematyki i problematyki oraz przestrzegania tych samych zasad konstrukcyjnych poetyka poszczególnych powieści rodzinnych różni się — tak jest choćby w przypadku „klarownej” poetyki Nocy i dni i „ornamentalnej wybujałej stylistyki” powieści rosyjskich, np. Rodu pržekletego Iwana Rukawisznikowa (Szymonik 1994: 98).

Przegląd najważniejszych ujęć odmian gatunkowych związanych z tematyką rodzinną daje obraz łatwo uchwytnych powiązań pomiędzy nimi i każe zastanowić się, czy tak wyraźne oddzielanie ich od siebie jest zasadne. Powracające we wszystkich egzemplifikacje literackie, podobne lub identyczne cechy gatunkowe, ten sam temat wiodący, a także niekonsekwencje terminologiczne moga być przesłankami do rozważenia jednej wspólnej, obejmującej pozostałe podgatunki, szerszej odmiany gatunkowej powieści, jaką byłaby saga rodzinna. 


\section{Saga rodzinna - zarys koncepcji gatunku}

Tak często przywoływane w literaturze przedmiotu zmącenie form gatunkowych dotyczy nie tyle, jak twierdzi Ryszard Nycz, konkretnych wypowiedzi, co ogólnego układu odniesienia możliwych realizacji konwencji (2000: 92-93). Gatunki współczesne - sylwiczne, hybrydyczne, multimedialne - tworzą coraz bardziej nieoczywiste ciagi gatunkowe. Coraz częstsze okazuje się przemieszanie form podawczych, a podważenie sensowności opozycji fikcja - realność, powieść - literatura faktu czy przeszłość - teraźniejszość w ramach jednej odmiany gatunkowej, tak jak ma to miejsce w apokryfie rodzinnym (Medecka 2007: 29), nie wydaje się niczym niezwykłym.

Po przeanalizowaniu pokrewnych odmian gatunkowych chciałabym zaproponować ujęcie sagi rodzinnej jako obszerny utwór narracyjny opisujący dzieje rodziny przez kilka pokoleń na tle przeobrażé́ społeczno-kultu row y ch. Przy czym należałoby wyróżnić dwa typy sagi rodzinnej:

a. powieściowa (powieść rodzinna) — która byłaby odmiana gatunkowa powieści;

b. dokumentalna - w obrębie której znalazłyby się relacje o charakterze biograficznym i autobiograficznym — wspomnieniowym, genealogicznym, kronikarskim.

Saga powieściowa może być powieścią o cechach kroniki, zaś dokumentalna — przypominać upowieściowioną kronikę. W moich dalszych badaniach interesowałby mnie pierwszy typ sagi rodzinnej i te reprezentacje, które można by sytuować na pograniczu obydwu typów, podobnie jak usytuowałabym apokryf rodzinny zdefiniowany przez Medecka, który jest zarazem powieścią historyczną i autobiografią z elementami fikcji („,beletryzowana kronika"). Dlatego też nie poświęcam wiele uwagi sagom dokumentalnym, choć byłby to z pewnościa godny spenetrowania obszar badawczy.

Saga rodzinna powieściowa to odmiana powieści - powieść (wielo- lub jednotomowa) albo cykl narracyjny. Głównym komponentem strukturalnym byłby zatem temat, czyli dzieje rodziny przez kilka pokoleń i tło historyczne. Jak pisze Danuta Szymonik: „(...) saga rodzinna jest tym gatunkiem, który wnikając w problemy egzystencji i ontologii najmniejszej komórki społecznej, jaka jest rodzina, utrwala specyficzne cechy i właściwości tego kręgu spraw narodowych i kulturowych, do jakiego należy autor" (1999: 133). Byłby to typ powieści łączący w sobie cechy powieści realistycznej, powieści psychologicznej, powieści-rzeki (mógłby też całkowicie wchłoną́ tę odmianę gatunkową jako swój podtyp), powieści kroniki i powieści historycznej. Do cech powieści rodzinnej należałyby:

a. podporzaddkowanie fabuły opisowi dziejów jednego rodu lub — rzadziej — jednego bohatera na tle losów rodu i następstwa pokoleń,

b. c z a s jako zasadniczy element struktury utworu,

c. linearność $\mathrm{i}$ wielowątkowość fabuły,

d. czas fabuły obejmujący co najmniej dziesięć lat ${ }^{7}$,

e. realistyczność opisu wydarzeń i tła społeczno-historycznego,

f. współczesny lub przeszły czas fabuły,

Jest to, rzecz jasna, wartość umowna, wyprowadzona z tradycji gatunku konstytuującej się w początkach $\mathrm{XX}$ wieku i nie stanowi warunku sine qua non, podobnie jak inne cechy. Obszerniej na ten temat piszę w ostatniej część artykułu. 
g. przewaga narracji auktorialnej z elementami innych typów opowiadania i wstawkami w postaci np. pamiętników czy listów,

h. epicka rozlewność narracji mająca podkreślić wrażenie upływającego czasu,

i. bohaterowie charakteryzowani zewnętrznie i wewnętrznie,

j. fabularne powiązania raczej przestrzenno-czasowe niż przyczynowo-skutkowe. Warto dodać, iż w tak zarysowanym schemacie powieściowym mieściłyby się także utwory literackie zaliczanie do tzw. literatury popularnej czy literatury kobiecej, które spełniałyby kryterium tematyczne i podstawowe kryteria strukturalne.

Podkreślone główne punkty krystalizacji gatunku to obok tematu, czyli dziejów rodziny przez kilka pokoleń, także czas i opowiadanie — narracja prowadzona w sposób ciagły, linearnie, niekiedy nawiązująca do gawędy czy skazu. Nacisk na opowiadanie odróżniałby sage — warto tu przypomnieć etymologię tego terminu ${ }^{8}$ — od innych gatunków „rodzinnych”, np. kroniki posługującej się między innymi formą kalendarium. Czas to jednak kryterium równie ważne dla sagi rodzinnej. Przywołując koncepcję Kazimierza Wyki, można by stwierdzić, że czas narracji ${ }^{9} \mathrm{w}$ sadze jest względnie krótszy od czasu zdarzeń - narrator z perspektywy czasowej opowiada o wydarzeniach z wielu lat — jednak, jak twierdzi badacz, to tylko pozór, ponieważ powieść nie mogłaby wtedy powstać jako całość artystyczna (Wyka 1983: 316-317). Niemniej jednak rozmach czasu fabuły to jeden z wyznaczników gatunkowych sagi i czas narracji powinien wydawać się krótszy niż czas zdarzeń powieściowych. Zarazem horyzont czasowy narracji, aby sugerować panoramiczność oglądu, musi być odpowiednio duży (Bartoszyński 1991: 109). Łączy się z tym to, co nazwałam „obszernościa”, a więc długość/grubość utworu liczona w jednostkach długości tekstu, jak chciał Kazimierz Bartoszyński. Należy liczyć się z nieprecyzyjnością takiego kryterium i względnościa pojęcia „obszerny”, jest to jednak ważny element, który wpływa na konstrukcję sagi.

Z czasem i tematem wiąże się także konieczny realizm — przynajmniej powierzchowna zgodność czasu narracji i czasu zdarzeń z tłem historycznym, a jeśli autor pisze o czasach mu współczesnych, to także z tzw. czasem środowiska ${ }^{10}$. Odejście od przestrzegania zgodności powoduje zmianę gatunku — z powieści realistycznej na powieść fantasy.

Wiele spośród wymienionych cech pokrywa się z ustaleniami Szymonik z zakresu badań nad literaturą rosyjską. Do najczęściej powracających motywów i wątków należałyby ${ }^{11}$ : upadek określonej klasy społecznej (burżuazji, mieszczaństwa, ziemiaństwa, szlachty), najczęściej reprezentowanej przez najstarsze lub średnie pokolenie bohaterów; przemiany historyczne jako determinanty bytu grup społecznych i jednostek; występowanie czasu biologicznego i historycznego; „stopizowany” motyw domu rodzinnego jako

8 Pobocznym problemem badawczym, którego nie rozwinę w tym szkicowym artykule, byłaby relacja współczesnych sag do pierwotnej oralności gatunku: czy to kontynuacja monologicznego toku opowiadania, czy raczej polifonicznej tradycji powieści.

9 Czas narracji — płaszczyzna umownego czasu wewnątrz utworu, w której pisarz umieszcza narrację (może opowiadać o wydarzeniach dziejących się lub minionych) i czas zdarzeń powieściowych (czas, w którym rozwijają się wydarzenia). Zob. więcej: Wyka 1983.

10 Czas środowiska - czas znany pisarzowi, płaszczyzna czasowa związana ze środowiskiem, z którego się wywodzi lub które jest mu znane osobiście, czas, z którym musi on się liczyć. Zob. więcej: Wyka 1983. 
motyw kluczowy; zasady moralności rodowej jako podstawa istnienia „kosmosu rodowego" (miłość małżeńska, związek krwi, własność rodowa) — zachowanie tych zasad utrzymuje ład, zaś ich zerwanie powoduje chaos i zakłócenie norm nie tylko rodzinnych, ale i społecznych; gniazdo rodzinne rozpatrywane w kategorii sacrum; motyw drogi jako metafora losu pokoleń i poszczególnych postaci; motyw powrotu do korzeni i odejścia z domu rodzinnego - wyjścia młodej generacji z „,ram rodzinno-bytowych” (często prowadzi do destrukcji); duże znaczenie codzienności (rytualizacja codzienności) i tradycji; istotna rola wspomnień i przeszłości; dialog pokoleń i konflikt pokoleń jako nieodzowne elementy fabuły.

Tak scharakteryzowana odmiana gatunkowa mogłaby stać się nadrzędna dla dotychczasowych ujęć gatunków pokrewnych, m.in. niedookreślonej powieści-rzęei. Podobnie jak apokryf rodžinny na przecięciu sagi rodzinnej powieściowej i dokumentalnej znalazłaby się choćby powieść $W$ ogrodzie pamieci Joanny Olczak-Ronikier, przez niektórych uważana za powieść historyczną czy „wielopokoleniową sagę rodzinną” (Lemann 2008: 178), przez innych za rodzaj autobiografii: „Ten tekst zaliczyć wypada raczej do literatury faktu niż do powieści” (Medecka 2007: 151). Zdaniem Natalii Lemann jest to zarówno literatura, jak i mikrohistoria (2008: 178), a więc utwór pograniczny.

Wizerunek rodziny w literaturze, zwłaszcza $\mathrm{w}$ powieści rodzinnej, tak mocno osadzonej w realiach współczesnych autorowi, staje się doskonałym materiałem do analiz o charakterze antropologicznym. Warte zbadania wydaje się choćby zagadnienie związku pomiędzy ewolucją semantyki postrzegania rodziny a rozwojem gatunku literackiego. Monika Brzóstowicz zauważa tego rodzaju zależności m.in. w utworach Witolda Gombrowicza i pisze, że nastapiła: „realna zmiana sensu rodzinnej wspólnoty: z instytucjonalnego (społecznego) na personalistyczny (indywidualny)" (1998: 197). Czy dalsze przekształcenia w społecznym wizerunku rodziny i domu rodzinnego wpływają na stan sagi rodzinnej w XXI wieku?

\section{W stronę sagi rodzinnej XXI wieku}

Narzędzia genologii kulturowej wydają się właściwe do dalszych poszukiwań badawczych w obrębie przekształceń sagi rodzinnej jako gatunku i przydatne do otwierania interesujących pól interpretacyjnych. Przełom XX i XXI wieku został w literaturze naznaczony powrotem sagi, także w Polsce, gdzie w ostatnich latach powstało wiele powieści nawiązujących do opisywanej przeze mnie tradycji genologicznej. Obszerne epickie opowieści o dziejach rodów uwzględniają doświadczenie poprzednich epok, lecz - co będzie oczywistym wnioskiem, jednak koniecznym do zwerbalizowania — przepisują je w sposób typowy dla kultury współczesnej twórcom i czytelnikom XXI wieku. Zmienne historycznie modele rodziny i zmienne historycznie modele opowiadania, nakładając się na siebie, tworzą sagi rodzinne nowatorskie, wymykające się klasycznym ramom gatunkowym. W kolejnych kilku akapitach nakreślam problemy, z którymi spotyka się badacz sięgający po takie właśnie utwory, jednak nie sposób opisać ich szerzej w niniejszym tekście mającym za zadanie przede wszystkim uporządkować pojęcia.

Wydaje się, że można wyróżnić dwa podstawowe kierunki rozwoju sagi. Po pierwsze byłyby to utwory zachowujące w dużej mierze przedstawiony wzorzec klasycznej powieści rodzinnej, respektujące wszystkie lub większość cech wymienionych w poprzedniej części niniejszego artykułu (zob. punkty: a-j); przeważnie trzeba by tu 
mówić o reprezentacji szeroko rozumianej literatury popularnej, zwłaszcza tzw. literatury kobiecej. Jako egzemplifikacje moga posłużyć powieści takich autorek, jak Małgorzata Gutowska-Adamczyk, Joanna Miszczuk czy Agnieszka Janiszewska, a także, w pewnych aspektach, Małgorzata Kalicińska i Katarzyna Grochola. Jednak nawet w ich utworach można zauważyć już wyraźne odstępstwa od XX-wiecznej koncepcji powieści rodzinnej, choćby matrylinearność będąca naturalnym następstwem eksploracji teorii feministycznych na gruncie filozofii, socjologii czy kulturoznawstwa i literaturoznawstwa. Przenikanie „kulturowych teorii literatury” do dyskursu popularnonaukowego, a z czasem do świadomości społeczeństwa sprawia, że pewnego rodzaju lustrem dla nich staje się kultura popularna. W przypadku powieści rodzinnych, o których można by powiedzieć, że sa pisane przez kobiety i dla kobiet, przykładowo wspomniany feminizm jest oczywiście odpowiednio uładzony i nie pełni roli dydaktycznej, bynajmniej nie w sposób zgodny z założeniami teorii. Pojawia się jednak, co jest warte odnotowania ${ }^{12}$. Trzeba wyraźnie zaznaczyć, mówiąc o tego rodzaju literaturze, że należy ona do kultury popularnej, a część powieści „kobiecych” nadal trzeba określić mianem kiczowatych.

Znacznie więcej odstępstw znajdziemy w drugiej grupie ${ }^{13}$ sag współczesnych: różnice strukturalne, sposób prowadzenia narracji (np. narracja prowadzona z perspektywy jednego bohatera, wielu narratorów, brak narratora auktorialnego lub narrator wprost komentujący i oceniający), czas fabuły i czas narracji (czas zawężony do nieokreślonego momentu, do „teraz”, w którym rozgrywa się wielopokoleniowa historia rodu; nielinearność, retrospektywność), problematyka (przewartościowanie „kosmosu rodowego”, zwrot w stronę wolnej jednostki, skomplikowane relacje mikro- i makrohistorii). Można by tu wskazać takie utwory, jak: Piaskowa Góra Joanny Bator, Chochoły Wita Szostaka, Bambino Ingi Iwasiów, W toskie szpilki (tym ciekawsze, że będące zbiorem opowiadań) i Szum Magdaleny Tulli, Balzakiana i Saturn Jacka Dehnela, Katoniela Ewy Madeyskiej, Szopka Zośki Papużanki czy Bura i sqał Aleksandry Zielińskiej. Warto rozważyć dla takich utworów wprowadzenie pojęcia a n ty s a gi, które przez nawiązanie do gatunku osadza nowe twory w kontekście historycznoliterackim, a zarazem podkreśla ich polemiczny stosunek do tradycji ${ }^{14}$.

Analiza powieści o tematyce rodzinnej powstałych w Polsce w ostatnim dziesięcioleciu, którą chciałabym się zająć w dalszych badaniach, mogłaby przynieść odpowiedź na pytanie o celowość aktualizowania formuły sagi rodzinnej, a także o to, czy wciąż powstaja tradycyjne powieści rodzinne, czy raczej możemy mówić już tylko o antysagach.

12 Jako przykład można wskazać przyzwolenie na pozamałżeńskie związki seksualne bohaterek niektórych powieści. Bywają one akceptowalne i nie niosa już za sobą zawsze negatywnych konsekwencji. Na temat kobiecych sag piszą badaczki związane z gender studies, m.in. Inga Iwasiów i Agnieszka Mrozik (Iwasiów 1999: 136-147; Encyklopedia gender 2014: 500).

13 Granica między nimi jest tak samo trudna do wytyczenia jak granica między literaturą popularną a wysoka, dawno już zatarta przez badaczy, a jednak wciąż w pewnych sytuacjach funkcjonalna. Szczególnie interesujące okazują się utwory niedające się łatwo usytuować po żadnej ze stron, np. wydana w 2017 roku powieść (saga rodzinna promowana jako pierwszy polski serial literacki) Ewy Madeyskiej Rodzina O.

14 Ponownie porzucam drugą gałąź sag, czyli sagi dokumentalne i ich przekształcenia w literaturze najnowszej. Pisze o nich nieco Andrzej Zieniewicz w tekście Opowieści rodżinne, analizując utwory Joanny Olczak-Ronikier, Janiny Kumanieckiej, Agaty Tuszyńskiej i Krzysztofa Teodora Toeplitza (zob. Zieniewicz 2007). 


\section{Bibliografia}

Bartmiński Jerzy (2012), Jak opisywać gatunki mowy? [w:] Jezyka a Kultura, Tom 23, Akty i gatunki mowy w perspek.tymie kulturowej, red. A. Burzyńska-Kamieniecka, Wydawnictwo Uniwersytetu Wrocławskiego, Wrocław.

Bartoszyński Kazimierz (1991), Konstruk.cje czasu w literaturze polskiej XX wieku (S zkic syntery) [w:] K. Bartoszyński, Powieść w świecie literackości, IBL, Warszawa.

Brzóstowicz Monika (1998), Wizerunek rodziny w polskiej prozie wspótczesnej, „Poznańskie Studia Polonistyczne", Poznań.

Cambridge Advanced Dictionary (2013), ed. C. McIntosh, Cambridge UP, Cambridge.

Collins Cobuild English Dictionary (1995), Harper Collins Publishers, London.

Czermińska Małgorzata (2000), Autobiograficzny trójkąt: świadectwo, wyそnanie i wyzwanie, Universitas, Kraków.

Czermińska Małgorzata, red. (2009), Autobiografia, słowo/obraz terytoria, Gdańsk.

Duden Deutsches Universalworterbuch (2015), Dudenverlag, Berlin.

Encyklopedia gender (2014), red. M. Rudaś-Grodzka i in., Czarna Owca, Warszawa.

Frydrych(a)s Anna (1965), Problematyka roman-flewve (powieśsi ręeki), rozprawa doktorska, dostęp: Archiwum Uniwersytetu Lódzkiego.

- (1967), Problemy roman-flewve (powieści-rzeki), „Biuletyn Polonistyczny”, z. 28.

Geertz Clifford (1996), O gatunkach zmaconych (Nowe konfiguracje myśli społecznej), przeł. Z. Lapiński [w:] Postmoderniżm. Antologia przekeładón, red. R. Nycz, Wydawnictwo Baran i Suszyński, Kraków.

Głowiński Michał (2013), O gatunkach literackich — po latach [w:] Tradycja i prayszłość genologii, red. D. Kulesza, Wydawnictwo Uniwersytetu w Białymstoku, Białystok.

Górski Artur, oprac. (1960), Sagi islandzkie, Ludowa Spółdzielnia Wydawnicza, Warszawa.

Iwasiów Inga (1999), Gender dla średnio zaawansowanych, WAB, Warszawa.

Jakowska Krystyna (2001), Cykl opowiadań — próba bistorii. Intuicje i sugestie [w:] Cykl literacki w Polsce, red. K. Jakowska, B. Olech, K. Sokołowska, Trans Humana, Białystok.

- (2005), Tryptyk jako odmiana cyklu literackiego [w:] Semiotyka cyklu. Cykl w musyce, plastyce i literaturze, red. M. Demska-Trębacz, K. Jakowska, R. Sioma, Trans Humana, Białystok.

- (2011), O cyklu opowiadań. Z teorii i historii cyklu narracyjnego w Polsce, Trans Humana, Białystok.

Lemann Natalia (2008), Epicka historiografia we wspótczesnej prozie polskiej, Wydawnictwo Ut, Łódź.

- (2012), Saga [w:] Stownik rodzajón i gatunkón literackich, red. G. Gazda, PWN, Warszawa.

Makuch Damian Włodzimierz (2015), Zalety kulturowej teorii gatunku w pracy bistoryka literatury na pryyktadzie polskiej fantastyki naukowej drugiej potowy XIX wieku [w:] Porozmawiajmy o gatunkach artystycznych i usiytkowych, red. E. Bulisz, M. Wojtak, Wydawnictwo UMCS, Lublin.

Medecka Małgorzata (2007), Apokryf rodzinny jako odmiana dwudziestowiecznej powieści historycznej, Wydawnictwo UMCS, Lublin.

Morawiec Jakub, Neubauer Łukasz (2015), Wstęp [w:] Sagi island₹kie. Zarys dziejów literatury staronordyckiej, red. J. Morawiec, Ł. Neubauer, PWN, Warszawa.

Nycz Ryszard (1996), Sylwy wspótczesne, Universitas, Kraków.

- (2000), Tekstowy świat, Universitas, Kraków.

Pospíšil Ivo (2012), Powieść kronika [w:] Stownik rodzajów i gatunków literackich, red. G. Gazda, PWN, Warszawa. 
Sawicki Stefan (1976), Gatunek literacki: pojecie klasyfikacyjne, typologiczne, politypiczne [w:] Problemy metodologiczne wspótczesnego literaturoznanstwa, red. H. Markiewicz, J. Sławiński, Wydawnictwo Literackie, Kraków.

Schlauch Margaret (1976), Stare sagi island₹kie, Wiedza Powszechna, Warszawa.

Sendyka Roma (2012), W strone kulturowej teorii gatunku [w:] Kulturowa teoria literatury, red. R. Nycz, M. P. Markowski, Universitas, Kraków.

Sierotwiński Stanisław (1966), Stownik terminów literackich, Ossolineum, Wrocław-Warszawa-Kraków.

Skrzypek Dominika (2015), Sagi wspótczesne (samtidasögur) [w:] Sagi island₹kie. Zarys driejów literatury staronordyckiej, red. J. Morawiec, Ł. Neubauer, PWN, Warszawa.

Skwarczyńska Stefania (1954), Wstęp do nauki o literaturze, t. 1, Wydawnictwo PAX, Warszawa.

- (1987), Nie dostrzeżony problem podstawowy genologii [w:] Problemy teorii literatury, t. II, Ossolineum, Wrocław.

Szajnert Danuta (2000), Mutacje apokryfu [w:] Genologia dzisiaj, red. W. Bolecki, I. Opacki, Wydawnictwo IBL, Warszawa.

- (2014), Apokryf literacki [hasło], „Zagadnienia Rodzajów Literackich”, t. LVII, z. 2(114).

Szymonik Danuta (1999), Kosmos rodowy w literaturach stowiańskich poczatku XX wieku. (Na materiale literatury bułgarskiej i rosyjskiej) [w:] Zwiqzki międsy literaturami narodów stowianskich w XIX i XX wieku, red. W. Kowalczyk, Wydawnictwo UMCS, Lublin.

- (1987), Poetyka sagi rosyjskiej poczqtku XX wieku. Czas i przestrzeńn [w:] Literatura rosyjska i radzieck a a bistoria. Motyny, poetyka, red. A. Wieczorek, Opole.

- (1994), Rosyjska kronika rodzinna poczatku wieku XX w kontekśsie „Nocy i dni” Marii Dabrowskiej [w:] Polsko-wschodniostowianskie powiazania kulturowe, literackie i jezykowe. 1. Literatura $i$ kultura, red. A. Bartoszewicz, Wydawnictw WSP w Olsztynie, Olsztyn.

- (1997), Rosyjska powieść rodowa lat dziesiatych XX wieku w kontekście narratologii [w:] Ze studiów nad literatura rosyjska XIX $i$ XX wieku. Cztowiek i prayroda w literaturze rosyjskiej. Tom II, red. M. Cymborska-Leboda, Lublin.

- (2003), Rosyjska powieść rodzinna Srebrnego Wieku, Wydawnictwo UMCS, Lublin.

Todorov Tzvetan (1979), O pochodzeniu gatunków, przeł. A.W. Labuda, „Pamiętnik Literacki”. The Oxford English Dictionary (1991), vol. XIV, Clarendon Press, Oxford.

The Random House Collage Dictionary (1984), ed. J. Stein, Random House, New York.

Wierzbicki Jan (1975), Miroslav Krleza, Wiedza Powszechna, Warszawa.

Witosz Bożena (2001), Gatunek — sporny (?) problem wspótcz̨esnej refleksji tekstologicznej, „Teksty Drugie", nr 5.

- (2005), Genologia lingwistyczna. Zarys problematyki, Wydawnictwo UŚ, Katowice.

Wojtak Maria (2015), Dylematy genologa [w: Porozmawiajmy o gatunkach artystycznych i u̇̃ytkowych, red. E. Bulisz, M. Wojtak, Wydawnictwo UMCS, Lublin.

Wołk Marcin (2004), Autobiografirm i cykliczność [w:] Cykel i powieść, red. K. Jakowska, D. Kulesza, K. Sokołowska, Trans Humana, Białystok.

Wyka Kazimierz (1983), Teoria czasu powieściowego. Wyglad problemu [w:] Genologia polska. Wybór tekstów, red. E. Miodońska-Brookes i in., PWN, Warszawa.

Zieniewicz Andrzej (2007), Opowieści rodzinne [w:] Nowe formy w literaturze popularnej, red. B. Owczarek, J. Frużyńska, Wydział Polonistyki UW, Warszawa.

Złatanowa Nadia (1993), Genealogie jako pręedmiot badań humanistycznych, „Kultura i Społeczeństwo", tom 37 , nr 1. 